\title{
Channelizing the red blood cell: molecular biology competes with patch-clamp
}

\author{
Lars Kaestner* \\ Research Center for Molecular Imaging and Screening, Medical School, Saarland University, Homburg, Germany
}

Keywords: erythrocyte, Gardos channel, Piezo1, patch-clamp techniques, ion channels

Both patch-clamp and molecular biology provide powerful tools to investigate ion channels. However, the approaches couldn't be more different. While patch-clamp probes protein function on the scale of a single cell or even down to a single molecule, molecular biology includes techniques that identify the protein, and requires mostly cell populations. According to current knowledge and compared to other cell types, red blood cells (RBCs) possess a rather small variety of ion channels. Nevertheless, both techniques are still revealing new channels. The challenge is to keep the results of both methods in agreement. Such consistency can be shown for a number of channels; just to name successful examples, the voltage-dependent anion channel (VDAC) (Bouyer et al., 2011, 2012) and the NMDA-receptor (Makhro et al., 2013; Hänggi et al., 2014). However, providing a general correlation between patch-clamp and molecular biology derived results has had limited success (Kaestner, 2011; Bouyer et al., 2012). One reason for this difficulty is that techniques themselves or their particular application have certain shortcomings.

Patch-clamp, although an extremely powerful technique to investigate RBCs (Hamill, 1983), is in the $\mathrm{RBC}$ research field sometimes presented in a rather fragmentary way. An example is a channel, published in 2000, that was supposed to be induced in RBCs by the malaria parasite (Figure 2 in Desai et al., 2000). In contrast, a channel with very similar properties had already been described in healthy RBCs in 1989 (Figure 6 in Schwarz et al., 1989). After years of debate (for examples, see Egée et al., 2002; Huber et al., 2002; Staines et al., 2003, 2007), it became accepted that the increased conductance in malaria infected RBCs was mediated by endogenous ion channels of RBCs (Bouyer et al., 2007).

For molecular biology-based investigations, RBCs impose a twofold challenge:

(i) Most genetic approaches are limited to precursor cells, because mammalian RBCs contain neither a nucleus nor ribosomes as a translational machinery.

(ii) It appears to be extremely difficult to isolate pure preparations of RBCs (Minetti et al., 2013). Even in cell preparations filtered on cellulose (Beutler et al., 1976), RNA of tyrosine phosphatase (CD45-a marker for non-RBCs) was found in next generation sequencing. Only further fluorescence-activated RBC sorting revealed CD45-free preparations.

Therefore, proofs for the molecular identity of ion channels in RBCs often include indirect methods.

For example, the Gardos channel, named after an effect initially described by George Gardos based on flux-experiments (Gardos, 1958), was the first channel shown in human RBCs by patch-clamp using single channel recordings (Hamill, 1981). The Gardos channel was later identified to be encoded by the KCNN4 gene ( $\mathrm{K}_{\mathrm{Ca}} 3.1$ protein, also called hSK4 channel) (Hoffman et al., 2003). Although the RT-PCR of reticulocytes and the Western blots of RBCs look convincing one needs to consider point (ii) above. All other arguments such as Northern blots of human erythroid progenitor cells or properties of heterologously expressed KCNN4 vs. KCNN3 
(Hoffman et al., 2003) are indirect in nature. On the patchclamp side one can find numerous single channel recordings of the Gardos channel (Hamill, 1981, 1983; Grygorczyk et al., 1984; Schwarz et al., 1989), but whole cell recordings are almost missing. Some electrophysiologists even believe the Gardos channel is unmeasurable in the whole-cell configuration of RBCs. I am only aware of one paper in which the authors were courageous enough to publish whole-cell recordings of the Gardos channel in human RBCs (Kucherenko et al., 2013). The lack of more attempts is not surprising considering the estimation of the number of channels per cell based on single channel recordings at approximately 10 (Grygorczyk et al., 1984), which renders whole-cell recordings difficult.

Another example is Piezo1-this mechano-sensitive channel was only recently discovered (Coste et al., 2010) and associated with the anemic disease hereditary xerocytosis (HX) due to mutations of Piezol found in HX patients (Zarychanski et al., 2012). Pharmacological modulations in patch-clamp experiments suggest that Piezo1 may also contribute to $\mathrm{P}_{\text {sickle }}$ in sickle cell disease RBCs (Bae et al., 2011; Ma et al., 2012; Gallagher, 2013). Beside all these findings and a biophysical characterisation of Piezol in heterologous expression systems (Bae et al., 2011; Gottlieb and Sachs, 2012), the channels' direct functional or molecular proof in human RBCs remains rather elusive-patch-clamp recordings in HX RBCs lack (statistical) comparison in healthy controls (Figure 2 in Archer et al., 2014). Although Piezol abundance and function in mouse RBCs has been shown (Cahalan et al., 2015), so far I have not seen any convincing Piezol protein data, such as immunocytochemistry or Western blots, based on human RBCs. However, indirect evidence, e.g., measurements of Gardos channel activity induced by membrane deformations (Dyrda et al., 2010), where deformations are likely to activate Piezol eventually triggering Gardos channel activity, contribute to the overall picture.

The intention to present these prominent examples is not to doubt the existence of the Gardos channel or the Piezo1 in RBCs, but to illustrate the difficulties in revealing channel identities or saying it with other words: bringing electrophysiology and molecular biology into agreement. To achieve this goal it seems

\section{References}

Achilli, C., Ciana, A., Balduini, C., Risso, A., and Minetti, G. (2011). Application of gelatin zymography for evaluating low levels of contaminating neutrophils in red blood cell samples. Anal. Biochem. 409, 296-297. doi: 10.1016/j.ab.2010.10.019

Archer, N. M., Shmukler, B. E., Andolfo, I., Vandorpe, D. H., Gnanasambandam, R., Higgins, J. M., et al. (2014). Hereditary xerocytosis revisited. Am. J. Hematol. 89, 1142-1146. doi: 10.1002/ajh. 23799

Bae, C., Sachs, F., and Gottlieb, P. A. (2011). The mechanosensitive ion channel Piezo1 is inhibited by the peptide GsMTx4. Biochemistry 50, 6295-6300. doi: 10.1021/bi200770q

Beutler, E., West, C., and Blume, K. G. (1976). Removal of leukocytes and platelets from whole-blood. J. Lab. Clin. Med. 88, $328-333$. compulsory to consider some points when investigating ion channels in RBCs:

(a) Functional studies are always most convincing. Beside patchclamp recordings those include fluorescence-based methods and tracer flux experiments. Conviction increases if it can be proved that effects originate exclusively from RBCs [see point (ii) above]. This condition is relatively easily met when experiments are performed on single cells under visual inspection, such as patch-clamp or fluorescence imaging.

(b) Cell population measurements require purification efforts. Centrifugation based methods are insufficient (Minetti et al., 2013). Additional filtering, e.g. through cellulose (Beutler et al., 1976), improves the situation. Filtering should be followed by a gelatine zymography (Achilli et al., 2011), which works fine for human RBCs but is insufficient for mouse RBCs. Quantification through assays detecting tyrosine phosphatase is even better. For really pure RBC preparations high quality sorting procedures based on CD45 antibodies should be implemented.

(c) Patch-clamp recordings require a full characterisation based on ion selectivity and other biophysical or pharmacological parameters. Channel identification should not preferentially rely on the appearance of traces or the general compatibility of the trace with the hypothesis (e.g, Kaestner and Bernhardt, 2002; Locovei et al., 2006; Archer et al., 2014).

Although sometimes one gets the impression that when RBCs are concerned, molecular biology competes with patch-clamp as indicated by the title, it is obvious and necessary that both techniques need to synergistically complement each other to effectively reveal the complexity of RBCs.

\section{Acknowledgments}

The author would like to thank Dr. Polina Petkova-Kirova for a lively discussion of the manuscript. The work leading to this comment has received funding from the European Seventh Framework Program under grant agreement number 602121 (CoMMiTMenT). 
Desai, S. A., Bezrukov, S. M., and Zimmerberg, J. (2000). A voltage-dependent channel involved in nutrient uptake by red blood cells infected with the malaria parasite. Nature 406, 1001-1005. doi: 10.1038/35023000

Dyrda, A., Cytlak, U., Ciuraszkiewicz, A., Lipinska, A., Cueff, A., Bouyer, G., et al. (2010). Local membrane deformations activate $\mathrm{Ca}^{2+}$-dependent $\mathrm{K}+$ and anionic currents in intact human red blood cells. PLoS ONE 5:e9447. doi: 10.1371/journal.pone.0009447

Egée, S., Lapaix, F., Decherf, G., Staines, H. M., Ellory, J. C., Doerig, C., et al. (2002). A stretch-activated anion channel is up-regulated by the malaria parasite Plasmodium falciparum. J. Physiol. (Lond.) 542, 795-801. doi: 10.1113/jphysiol.2002.022970

Gallagher, P. G. (2013). Disorders of red cell volume regulation. Curr. Opin. Hematol. 20, 201-207. doi: 10.1097/MOH.0b013e32835f6870

Gardos, G. (1958). The function of calcium in the potassium permeability of human erythrocytes. Biochim. Biophys. Acta 30, 653-654.

Gottlieb, P. A., and Sachs, F. (2012). Piezo1: properties of a cation selective mechanical channel. Channels (Austin) 6, 214-219. doi: 10.4161/chan.21050

Grygorczyk, R., Schwarz, W., and Passow, H. (1984). Ca ${ }^{2+}$-activated $\mathrm{K}^{+}$channels in human red cells. Comparison of single-channel currents with ion fluxes. Biophys. J. 45, 693-698. doi: 10.1016/S0006-3495(84)84211-3

Hamill, O. P. (1981). Potassium channel currents in human red blood cells. J. Physiol. Lond. 319, 97P-98P.

Hamill, O. P. (1983). "Potassium and chloride channels in red blood cells," in Single Channel Recording, eds B. Sakmann and E. Neher (New York, NY; London: Plenum Press), 451-471.

Hänggi, P., Makhro, A., Gassmann, M., Schmugge, M., Goede, J. S., Speer, O., et al. (2014). Red blood cells of sickle cell disease patients exhibit abnormally high abundance of $\mathrm{N}$-methyl D-aspartate receptors mediating excessive calcium uptake. Br. J. Haematol. 167, 252-264. doi: 10.1111/bjh.13028

Hoffman, J. F., Joiner, W., Nehrke, K., Potapova, O., Foye, K., and Wickrema, A. (2003). The hSK4 (KCNN4) isoform is the Ca2+-activated $\mathrm{K}+$ channel (Gardos channel) in human red blood cells. Proc. Natl. Acad. Sci. U.S.A. 100, 7366-7371. doi: $10.1073 /$ pnas.1232342100

Huber, S. M., Uhlemann, A. C., Gamper, N. L., Duranton, C., Kremsner, P. G., and Lang, F. (2002). Plasmodium falciparum activates endogenous $\mathrm{Cl}(-)$ channels of human erythrocytes by membrane oxidation. EMBO J. 21, 22-30. doi: 10.1093/emboj/21.1.22

Kaestner, L. (2011). Cation channels in erythrocytes-historical and future perspective. Open Biol. J. 4, 27-34. doi: 10.2174/187419670110 4010027

Kaestner, L., and Bernhardt, I. (2002). Ion channels in the human red blood cell membrane: their further investigation and physiological relevance. Bioelectrochemistry 55, 71-74. doi: 10.1016/\$1567-5394(01)00164-5
Kucherenko, Y. V., Wagner-Britz, L., Bernhardt, I., and Lang, F. (2013). Effect of chloride channel inhibitors on cytosolic $\mathrm{Ca} 2+$ levels and $\mathrm{Ca} 2+$-activated $\mathrm{K}+$ (Gardos) channel activity in human red blood cells. J. Membr. Biol. 246, 315-326. doi: 10.1007/s00232-013-9532-0

Locovei, S., Bao, L., and Dahl, G. (2006). Pannexin 1 in erythrocytes: function without a gap. Proc. Natl. Acad. Sci. U.S.A. 103, 7655-7659. doi: 10.1073/pnas.0601037103

Ma, Y.-L., Rees, D. C., Gibson, J. S., and Ellory, J. C. (2012). The conductance of red blood cells from sickle cell patients: ion selectivity and inhibitors. J. Physiol. (Lond.) 590, 2095-2105. doi: 10.1113/jphysiol.2012.229609

Makhro, A., Hänggi, P., Goede, J. S., Wang, J., Brüggemann, A., Gassmann, M., et al. (2013). N-methyl D-aspartate (NMDA) receptors in human erythroid precursor cells and in circulating red blood cells contribute to the intracellular calcium regulation. Am. J. Physiol. Cell Ph. 305, C1123-C1138. doi: 10.1152/ajpcell.00031.2013

Minetti, G., Egée, S., Mörsdorf, D., Steffen, P., Makhro, A., Achilli, C., et al. (2013). Red cell investigations: art and artefacts. Blood Rev. 27, 91-101. doi: 10.1016/j.blre.2013.02.002

Schwarz, W., Grygorczyk, R., and Hof, D. (1989). Recording single-channel currents from human red cells. Methods Enzymol. 173, 112-121.

Staines, H. M., Alkhalil, A., Allen, R. J., De Jonge, H. R., Derbyshire, E., Egée, S., et al. (2007). Electrophysiological studies of malaria parasiteinfected erythrocytes: current status. Int. J. Parasitol. 37, 475-482. doi: 10.1016/j.ijpara.2006.12.013

Staines, H. M., Powell, T., Ellory, J. C., Egée, S., Lapaix, F., Decherf, G., et al. (2003). Modulation of whole-cell currents in Plasmodium falciparum-infected human red blood cells by holding potential and serum. J. Physiol. (Lond.) 552, 177-183. doi: 10.1113/jphysiol.2003.051169

Zarychanski, R., Schulz, V. P., Houston, B. L., Maksimova, Y., Houston, D. S., Smith, B., et al. (2012). Mutations in the mechanotransduction protein PIEZO1 are associated with hereditary xerocytosis. Blood 120, 1908-1915. doi: 10.1182/blood-2012-04-422253

Conflict of Interest Statement: The author declares that the research was conducted in the absence of any commercial or financial relationships that could be construed as a potential conflict of interest.

Copyright (c) 2015 Kaestner. This is an open-access article distributed under the terms of the Creative Commons Attribution License (CC BY). The use, distribution or reproduction in other forums is permitted, provided the original author(s) or licensor are credited and that the original publication in this journal is cited, in accordance with accepted academic practice. No use, distribution or reproduction is permitted which does not comply with these terms. 